\title{
MONITORING OF THE QUALITY COMPLIANCE OF BOILED SAUSAGES WITH THE REQUIREMENTS OF THE NATIONAL STANDARD AND LEGISLATION
}

\author{
Khimych M. S., Rodionova K. O. \\ Odessa State Agrarian University, Odessa, Ukraine, \\ e-mail: khimichms@gmail.com, katerina.rodionova@ukr.net
}

\begin{abstract}
Summary. It is important to remember that the most important factor in forming the adult health is the proper diet of children. Despite the growing interest in a healthy lifestyle and diet all over the world, society tends to continue buying ready-made food, the use of which is associated with saving time on cooking. In Ukraine, the traditional meat products are sausage products, in particular, sausages. Studies of the diet of modern schoolchildren show that $35 \%$ of respondents constantly consume sausages. It is important to take into account that the main circumstance for the benefit of a food product is its safety for human consumption. The purpose of this work has been to analyze the compliance of certain indicators of safety and quality of sausages of the premium grade 'Dytiachi', which are manufactured by various domestic producers, to the requirements of DSTU 4436: 2005 'Boiled sausages, frankfurters, sardellas, meat loaves. General specifications'. The results of the analysis of the labeling of sausages 'Dytiachi' are presented in the article. They are testifying that in accordance with demanding to paragraph 1 of article 6 of the Law of Ukraine 'About information for consumers about food products' the labels contain basic production and consumer information. At the same time, there is no information provided by article 23 of this law on the labels of the samples: namely the mass of saturated fat and salt. It was also found that as a labeling part of the tested samples (No. 1, 2, and 4) the manufacturers use the statement 'Recommended for diet of preschool aged children (from 3 years) and children of school age', which is compliance/consistent with the text of DSTU 4436:2005 'Boiled sausages, frankfurters, sardellas, meat loaves. General specifications', but, contradict to articles 1 and 4 of part 4 of 'Requirements for claims on the nutritional value of foods and claims on the health benefits of foods'. According to the results of the study of the chemical composition, it was found that in the sample No. 2 the mass fraction of table salt was $2.11 \pm 0.14 \%$, which exceeds the content regulated by the state standard by $0.11 \%$
\end{abstract}

Keywords: safety, chemical composition, children diet, bacterial contamination, content of radionuclides

Introduction. The food market globalization has led to the need to solve the problem of food quality and safety and reduce the risks of their negative impact on population health (Kotelevych and Larina, 2020).

Today, providing the population with safe and quality food is of vital social and epidemiological importance, as it affects the quality of life and health of citizens (Paliy et al., 2020).

It is important to remember that the most vital factor in forming the health of an adult is the proper children diet. According to the WHO, $60 \%$ of a child's health depends on the quality and safety of food. That is, first of all, the diet of children that affects all processes of development of their body. Physical and mental potential, which is accumulated in childhood, ensure the health of an adult, and formed social and eating habits assist to the further formation of behavioral patterns for a healthy lifestyle (Hashchuk, Moskaliuk and Fedorko, 2014; Nyankovskyy and Sadova, 2018; Voitsitska, 2019; Merkulova et al., 2020).

Adequate nutrition is necessary for the growth and development of the body, so meat products are important in the human diet. Namely meat contains essential amino acids, B vitamins and vital minerals such as calcium, phosphorus, potassium and magnesium, which are especially important for the formation and maintenance of health in childhood (Bohatko et al., 2017; Buts, 2017; Rodionova and Paliy, 2018; Andryuschenko et al., 2020; Hashchuk, Moskaliuk and Simonova, 2020). However, despite the growing worldwide interest in a healthy lifestyle and diet, taking into account the pace of modern life, society continues to tend to buy ready meals and semi-finished products, the use of which is associated with saving time on cooking (Paliy et al., 2020). In particular, sausages are a traditional product of the food industry in Ukraine. According to the analysis of the modern Ukrainian market, sausages take the fourth place in the scale of products that are in constant demand among the population (Romaniuk, 2019; Paliy et al., 2020; Khimich et al., 2020).

Studies of the schoolchildren diet nowadays show that $45 \%$ of them regularly eat industrially produced food and $35 \%$ of the respondents mentioned sausages (Nyankovskyy and Sadova, 2018).

It is important to keep in mind that the main condition for the benefit of a food product is its safety for human consumption (Rodionova and Paliy, 2018; Khimich et al., 2020). A consumer is able to appreciate its marketable qualities-appearance and freshness buying a certain meat product. However, the buyer cannot judge the most important characteristic of sausages environmental and food safety by its appearance. The safety is characterized by the presence in the product of toxic substances, nitrosamines, pesticides, aflatoxin $\mathrm{B} 1$, hormonal drugs, radionuclides, etc. (Paliy et al., 2020). In addition, the rapid development of the food industry, the use of modern raw materials and the creation of new methods in food production, along with the economic crisis, have led to the rapid development of food additives and substitutes of natural ingredients in food, 
which can pose a danger to a child's health (Yevstafieva et al., 2017; Paliy et al., 2020; Skrypka et al., 2020; Tytarenko, 2020).

In this regard, the control of safety and quality of meat and meat products, especially recommended for children's diet is still relevant (Andryuschenko et al., 2020; Merkulova et al., 2020; Paliy et al., 2020).

The aim of the work has been to analyze the compliance of certain indicators of safety and quality of sausages of the premium grade 'Dytiachi' which are manufactured by various domestic producers, to the requirements of DSTU 4436:2005 'Boiled sausages, frankfurters, sardellas, meat loaves. General specifications' (DSSU, 2006).

Materials and methods. Experimental studies have been conducted on the basis of a multidisciplinary laboratory of veterinary medicine of the Odesa State Agrarian University, in accordance with current regulations: analysis of labeling in accordance with the Law of Ukraine 'About information for consumers about food products' (VRU, 2019); sampling and sensory evaluation of sausages in accordance with DSTU 4823.2:2007 (DSSU, 2008a); determination of chemical components (mass fraction of protein, fat, moisture, sodium chloride) has been done with using the express analyzer FoodScan Lab (Denmark); microbiological parameters have been determined in accordance with DSTU ISO 4833:2006 (ISO 4833:2003, IDT) (DSSU, 2008b) (content of Mesophilic-aerobic and facultative anaerobic microorganisms (MAFAnM)), DSTU ISO 4832:2015 (ISO 4832:2006, IDT) (SE 'UkrNDNC', 2018) (presence of coliform bacteria), DSTU ISO 15213:2014 (ISO 15213:2003, IDT) (SE 'UkrNDNC', 2016) (presence of sulphite-reducing clostridia in $1 \mathrm{~g}$ of product), DSTU ISO 6888-2:2003 (ISO 6888-2:1999, IDT) (DSSU, 2005a) (presence of staphylococci in $1 \mathrm{~g}$ of product), DSTU EN 12824:2004 (EN 12824:1997, IDT) (DSSU, 2005c) (presence of Salmonella spp. in $25 \mathrm{~g}$ of product), DSTU ISO 11290-2-2003 (ISO 11290-2:1998, IDT) (DSSU, 2005b) (presence of Listeria monocytogenes in $25 \mathrm{~g}$ of product); content of ${ }^{137} \mathrm{Cs}$ and ${ }^{90} \mathrm{Sr}$ radionuclides - by $\beta$ $\gamma$-spectrometry.

The objects of the study have been sausages of the premium grade 'Dytiachi' domestic producers: 'Sample 1' (Dnepropetrovsk Region), 'Sample 2' (Kirovograd Region), 'Sample 3' (Odesa Region), 'Sample 4' (Poltava Region).

Results and discussion. The results of the analysis of the quality and the presence of information on the labels of the experimental sausages are given in Table 1 .

From the data of the Table 1 it is seen that the labeling of all test samples contain mandatory information, which is regulated in paragraph 1 of article 6 of the Law of Ukraine 'About information for consumers about food products' (VRU, 2019).

However, article 23 of this law further foresees that mandatory information on the nutritious value of a food product must include 'the content of fats, saturated fats, carbohydrates, sugars, proteins and salt'. However, none of the samples contains information on the mass content of saturated fat and salt, and the carbohydrate content has been indicated only on the label of sample 2 .

After analyzing the list of the ingredients, it been determined that all tested samples contain such an ingredient as food additive E 250 (sodium nitrite), the presence of which is approved for usage in the meat processing industry to stabilize the color. At the same time, at this juncture it is well known that nitrites have a negative effect on health: they influence blood hemoglobin, which leads to lower blood pressure, weak heart and lung (especially dangerous for infants, children and people suffering from cardiovascular disease); damage the thyroid activity, and the gland, heart, central nervous system as well; cause poisoning, especially in infants; Nitrates and Nitrites are precursors of nitrate substitutes, which cause liver disease and have carcinogenic properties. In addition, the negative effects of sodium nitrite increase during heating, which is especially relevant king into account the common consumers' habit to cook or fry sausages (Tytarenko, 2020). In this regard, there is still a relevant question about the feasibility and safety of the use of sausages, especially recommended for children, such a food additive. In addition to the mandatory information, the packaging of all the test samples also contain some additional information: statements about the quality and safety of the product. Thus, the labeling of samples No. 1, 3 , and 4 indicates that the product is produced 'GMOfree'; sample 2 - 'from selected types of meat Beef $50 \% /$ Pork 40\%' and 'Soya been-free/Gluten-free', and the labels of samples No.1,2, and 4 contain the mark 'Recommended for preschool children (from 3 years) and school age'.

It is the label 'Recommended for nutrition of preschool children (from 3 years) and school age' that raises controversial questions. After all, the use of such a statement in food labeling can create the impression of safety and even the benefits of this product for consumption among the consumers.

The annexes to DSTU 4436:2005 'Boiled sausages, frankfurters, sardellas, meat loaves. General specifications' (DSSU, 2006) (Table A.2) is mentioned that 'Dytiachi sausages' are 'sausages recommended by the Ministry of Health for baby food'.

At the same time, approved by the order of the Ministry of Health of Ukraine 'Requirements for claims on the nutritional value of foods and claims on the health benefits of foods' (hereinafter - the Requirements) (MHU, 2020) do not contain among the lists of permitted claims (Annexes 2-3), and article 1 of part 4 of the Requirements states 'It is prohibited to use health claims that are not contained in Annex 2 or Annex 3'. In addition, article 4 of part 4 of the Requirements states that 'Recommendations or approvals by medical associations, nutritionists' associations and other organizations aimed to improve human health may be applied only if there is scientifically substantiated evidence for such recommendations and approvals'. 
Table 1 - Information for consumers about sausages of the premium grade 'Dytiachi' is indicated on the packaging of various manufacturers

\begin{tabular}{|c|c|c|c|c|}
\hline \multirow{2}{*}{$\begin{array}{l}\text { Experimental } \\
\text { indicator }\end{array}$} & \multicolumn{4}{|c|}{ Samples } \\
\hline & 1 & 2 & 3 & $\overline{4}$ \\
\hline Product name & \multicolumn{4}{|c|}{ Sausages 'Dytiachi' } \\
\hline $\begin{array}{l}\text { The document } \\
\text { according to which } \\
\text { the product is }\end{array}$ & \multicolumn{4}{|c|}{$\begin{array}{l}\text { DSTU 4436:2005 'Boiled sausages, frankfurters, sardellas, } \\
\text { meat loaves. General specifications' (DSSU, 2006) }\end{array}$} \\
\hline List of ingredients & $\begin{array}{c}\text { raw meat } 90 \% \text { (pork } \\
\text { skimmed semi-fat, } \\
\text { beef skimmed the first } \\
\text { grade, skimmed beef } \\
\text { of the highest grade), } \\
\text { refined sunflower oil, } \\
\text { chicken eggs, skimmed } \\
\text { milk powder, drinking } \\
\text { water, table salt, white } \\
\text { sugar, ground nutmeg, } \\
\text { pepper powder, } \\
\text { ascorbic acid } \\
\text { (antioxidant), color } \\
\text { fixative (sodium } \\
\text { nitrite) } \\
\end{array}$ & \begin{tabular}{|c|} 
meat $-90 \%$ (semi-fat \\
pork, first grade beef \\
from young animals, \\
premium beef), \\
drinking water, \\
sunflower oil, egg \\
powder, skimmed milk \\
powder, table salt, \\
sugar, antioxidant \\
sodium ascorbate, \\
ground nutmeg, ground \\
pepper, color stabilizer \\
sodium nitrite
\end{tabular} & \begin{tabular}{|l} 
skimmed meat: \\
first grade beef \\
$30 \%$, premium \\
beef $20 \%$, semi-fat \\
pork $40 \%$, refined \\
sunflower oil, \\
chicken eggs, \\
skimmed cow's \\
milk powder, table \\
salt, granulated \\
sugar, ground \\
nutmeg, ground \\
pepper, color \\
stabilizer (sodium \\
nitrite E 250) \\
\end{tabular} & $\begin{array}{c}\text { raw meat } 90 \% \text { (pork } \\
\text { skimmed semi-fat, } \\
\text { skimmed beef of the first } \\
\text { grade from young } \\
\text { animals, skimmed beef of } \\
\text { premium grade), } \\
\text { drinking water, refined } \\
\text { sunflower oil, egg } \\
\text { melange, skimmed cow's } \\
\text { milk powder, table salt, } \\
\text { sugar - on antioxidant } \\
\text { isoascorbate, ground } \\
\text { nutmeg, ground pepper, } \\
\text { color stabilizer - sodium } \\
\text { nitrite } \\
\end{array}$ \\
\hline $\begin{array}{l}\text { The nutritional value } \\
\text { of the product, } 100 \mathrm{~g}\end{array}$ & $\begin{array}{l}\text { protein not less } 12.0 \mathrm{~g}, \\
\text { fats not more } 17.0 \mathrm{~g}\end{array}$ & $\begin{array}{l}\text { protein not less } 12 \mathrm{~g}, \\
\text { fats not more } 17 \mathrm{~g}, \\
\text { carbohydrates }-0.9 \mathrm{~g}\end{array}$ & $\begin{array}{l}\text { proteins } 13.86 \%, \\
\text { fats } 17 \%\end{array}$ & $\begin{array}{l}\text { protein not less than } 12 \mathrm{~g} \text {, } \\
\text { fats not more than } 17 \mathrm{~g}\end{array}$ \\
\hline $\begin{array}{l}\text { Energy value of the } \\
\text { product, } 100 \mathrm{~g}\end{array}$ & $201 \mathrm{Kcal} / 840 \mathrm{~kJ}$ & $201 \mathrm{Kcal}(841 \mathrm{~kJ})$ & $201 \mathrm{Kcal}$ & $841 \mathrm{~kJ}(201 \mathrm{Kcal})$ \\
\hline $\begin{array}{l}\text { Storage conditions } \\
\text { and shelf life }\end{array}$ & $\begin{array}{c}\text { At relative humidity } \\
\text { not higher than } 75- \\
78 \% \text { at temperatures } \\
\text { from } 0 \text { to } 6^{\circ} \mathrm{C} \text {, packed } \\
\text { in the conditions of the } \\
\text { modified gaseous } \\
\text { environment: no more } \\
\text { than } 12 \text { days, provided } \\
\text { the integrity of the } \\
\text { package }\end{array}$ & $\begin{array}{c}\text { Packed under vacuum. } \\
\text { Storage conditions at } \\
\text { temperatures from } 0 \text { to } \\
6^{\circ} \mathrm{C} \text { and relative } \\
\text { humidity of } 70-80 \%- \\
15 \text { days. After opening } \\
\text { the package, use during } \\
48 \text { hours within the } \\
\text { expiration date }\end{array}$ & $\begin{array}{c}\text { In a protective } \\
\text { environment the } \\
\text { gas mixture. } \\
\text { Store at } \\
\text { temperatures from } \\
0 \text { to } 6^{\circ} \mathrm{C} \text {, humidity } \\
\text { of } 75-78 \%\end{array}$ & $\begin{array}{c}\text { If stored in an airtight } \\
\text { container for } 10 \text { days at a } \\
\text { temperature of } 0 \text { to } 6^{\circ} \mathrm{C} \\
\text { and relative humidity of } \\
75-78 \% .\end{array}$ \\
\hline $\begin{array}{l}\text { Name and location } \\
\text { of the manufacturer } \\
\text { (production facilities) }\end{array}$ & + & + & + & + \\
\hline $\begin{array}{l}\text { Additional marks } \\
\text { (statements) }\end{array}$ & $\begin{array}{l}\text { 'Recommended for } \\
\text { preschool and school } \\
\text { age children' } \\
\text { 'GMO FREE' }\end{array}$ & \begin{tabular}{|c|} 
'Recommended by the \\
Ministry of Health of \\
Ukraine for preschool \\
and school age children \\
(from 3 years old)' \\
WITHOUT SOYA \\
'Gluten Free' \\
'From selected meats' \\
'Beef 50\% / Pork 40\%"
\end{tabular} & 'GMO FREE' & $\begin{array}{l}\text { 'Recommended for } \\
\text { preschool (from } 3 \text { years } \\
\text { old) and school age } \\
\text { children' } \\
\text { 'GMO FREE' }\end{array}$ \\
\hline
\end{tabular}

Thus, we see that the current regulatory documentation is now inconsistent. On the one hand it regulates the technical requirements for the production of sausages, and on the other hand it sets the rules of labeling. In addition, in article 47 of 'The order of organization of food in educational institutions and children's health and recreation institutions' (CMU, 2021) states 'In educational institutions, health facilities and recreation is prohibited to order and use/sell technologically processed meat and fish products'. 
To sum up the analysis of current and project documentation, as well as data on the possible negative impact of certain ingredients, we consider it is unacceptable to use in the text of DSTU 4436:2005 (DSSU, 2006) the indication 'Sausages recommended by the Ministry of Health for baby diet', therefore it is necessary to update the national standard.

At the next stage of research, a visual and sensory analysis of prototypes has been conducted. Deviations in the appearance of experimental samples of sausages 'Dytiachi' of the premium grade were not detected.

After the external examination, sausages were cut and their consistency, color and appearance of minced meat, smell and taste were determined. It was found that the consistency of sausage bars 'sample 1' is elastic, but tender and juicy, minced meat on the cut surface is light pink and homogeneous, without grey spots and cavities; the smell and taste are pleasant, with a milky aftertaste, moderately spicy and moderately salty. The broth was transparent, slightly pink, with a few small drops of fat during the cooking of samples.

The study of organoleptic characteristics of sausages 'sample 2' found that the sausages had an elastic and tender texture, were juicy, the color of the cut surface is pale pink, homogeneous; the smell is specific and meaty, the taste is moderately salty, there is a moderate amount of spices and milky taste. During the cooking test, the broth turned out to be transparent, pale pink, fragrant, with single drops of fat on the surface.

The organoleptic of the sausages 'sample 3' revealed an elastic but friable consistency, pinkish-grey color of the sausage stuffing; pronounced characteristic smell, salty, with a moderate amount of spices, taste. In the way of cooking revealed that the broth is cloudy, pale pink with drops of fat on the surface.

The study of sausages 'sample 4' found that the consistency of the sausage is elastic, tender and juicy, and the minced meat in the cut is light pink and homogeneous; the smell is delicate and specific, a moderate amount of spices and salt is felt. The broth was pale pink, transparent, fragrant, with a few drops of fat on the surface.

Generalized results of sensory evaluation of sausages are shown in Fig. 1. The figure shows that the highest number of points -29.6 - scored sausages 'sample 2', sausage 'sample 1' and 'sample 4' also received quite high scores - 29.2 and 28.9 points, respectively. Instead, sausages 'sample 3' were significantly resigned to all studied indicators of the other studied samples and received the lowest overall score - 26.7. However, it is important to note that despite the significant difference in the number of scores obtained by the results of sensory evaluation, all samples meet the requirements of the national standard for organoleptic parameters.

According to the results of determining the mass fraction of the main components of the chemical composition of the experimental samples of sausages (Table 2), it was found that the mass fraction of protein ranged from $11.97 \pm 0.11$ to $13.7 \pm 0.26 \%$, mass fraction of fat - from $16.66 \pm 0.27$ to $17.01 \pm 0.31 \%$, mass fraction of moisture - from $64.6 \pm 0.23$ to $66.8 \pm 0.44 \%$, which meets the requirements of DSTU 4436:2005 (DSSU, 2006) depending on the manufacturer. Regarding the salt content, in sausages 'sample 1' $(1.98 \pm 0.01 \%)$, 'sample 2' $(1.96 \pm 0.08 \%)$ and 'sample 4' $(1.99 \pm 0.1 \%)$ its mass fraction met the requirements of the national standard, however in the product 'sample 2' the figure was $2.11 \pm 0.14 \%$, which is $0.11 \%$ higher than the norm regulated by DSTU 4436:2005 (DSSU, 2006).
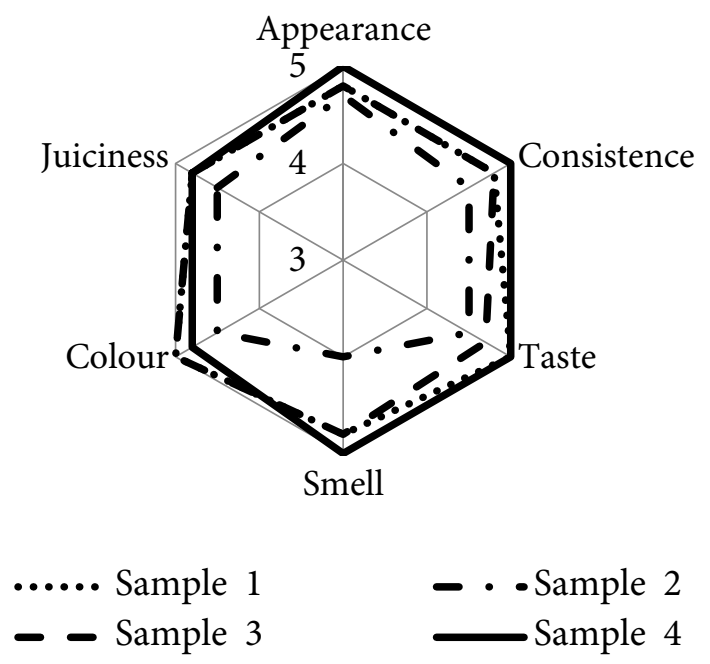

Figure 1. The results of sensory evaluation of sausages 'Dytiachi' premium grade from different manufacturers

Table 2 - Indicators of the chemical composition of sausages 'Dytiachi' premium grade, $M \pm m, n=5$

\begin{tabular}{|c|c|c|c|c|c|}
\hline \multirow[b]{2}{*}{$\begin{array}{l}\text { Name of } \\
\text { indicators }\end{array}$} & \multirow{2}{*}{\begin{tabular}{|l|} 
DSTU \\
requir- \\
ements
\end{tabular}} & \multicolumn{4}{|c|}{ Tested samples } \\
\hline & & Sample & Sample & Sample & Sample \\
\hline $\begin{array}{l}\text { Mass fraction } \\
\text { of protein, } \\
\text { not more } \\
\text { than, \% }\end{array}$ & 12.0 & $\begin{array}{c}12.1 \\
\pm 0.13\end{array}$ & $\begin{array}{c}13.17 \\
\pm 0.26\end{array}$ & $\begin{array}{c}11.97 \\
\pm 0,11\end{array}$ & $\begin{array}{c}11.9 \\
\pm 0.11\end{array}$ \\
\hline $\begin{array}{l}\text { Mass fraction } \\
\text { of fat, not } \\
\text { more than, \% }\end{array}$ & 17.0 & $\begin{array}{c}16.77 \\
\pm 0.54\end{array}$ & $\begin{array}{r}16.66 \\
\pm 0.27\end{array}$ & $\begin{array}{c}17.01 \\
\pm 0.31\end{array}$ & \begin{tabular}{|c|}
16.87 \\
\pm 0.22
\end{tabular} \\
\hline $\begin{array}{l}\text { Mass fraction } \\
\text { of moisture, } \\
\text { not more } \\
\text { than, } \%\end{array}$ & 68.0 & $\begin{array}{c}65.9 \\
\pm 0.48\end{array}$ & $\begin{array}{r}64.96 \\
\pm 0.23\end{array}$ & $\begin{array}{r}66.04 \\
\pm 0.51\end{array}$ & $\begin{array}{c}66.8 \\
\pm 0.44\end{array}$ \\
\hline $\begin{array}{l}\text { Mass fraction } \\
\text { of kitchen } \\
\text { salt, not more } \\
\text { than, \% }\end{array}$ & 2.0 & $\begin{array}{c}1.98 \\
\pm 0.01\end{array}$ & $\begin{array}{c}1.96 \\
\pm 0.08\end{array}$ & $\begin{array}{l}2.11 \\
\pm 0.1\end{array}$ & $\begin{array}{c}1.99 \\
\pm 0.11\end{array}$ \\
\hline
\end{tabular}

According to the results of microbiological studies (Table 3), it was found that all experimental samples of sausages meet the requirements of DSTU 4436:2005 (DSSU, 2006). The content of MAFAnM is in the range 
from $(1.7 \pm 0.13) \times 10^{2}$ to $(2.6 \pm 0.19) \times 10^{2} \mathrm{CFU} / \mathrm{cm}^{3}$. BGCP (coliform bacteria), sulfite-reducing clostridia and staphylococci in $1 \mathrm{~g}$ and salmonella and listeria in $25 \mathrm{~g}$ of the product were not detected.

According to the results of the study of the content of ${ }^{137} \mathrm{Cs}$ and ${ }^{90} \mathrm{Sr}$ radionuclides (Table 4), it was established that their content did not exceed the levels regulated by the national standard.

Table 3 - Microbiological indicators of sausages 'Dytiachi' premium grade, $\mathrm{M} \pm \mathrm{m}, \mathrm{n}=5$

\begin{tabular}{|c|c|c|c|c|c|}
\hline \multirow[b]{2}{*}{$\begin{array}{c}\text { Name of } \\
\text { indicators }\end{array}$} & \multirow{2}{*}{$\begin{array}{l}\text { DSTU } \\
\text { requir- } \\
\text { ements }\end{array}$} & \multicolumn{4}{|c|}{ Tested samples $\mathrm{X} \times 10^{2} \mathrm{CFU} / \mathrm{cm}^{3}$} \\
\hline & & San & $\begin{array}{c}\text { Sample } \\
2\end{array}$ & Sample & $\begin{array}{c}\text { Sample } \\
4\end{array}$ \\
\hline & & & 3 & $\begin{array}{r}2 . \\
\pm 0\end{array}$ & \pm \\
\hline
\end{tabular}

Table $4-$ The content of radionuclides in sausages 'Dytiachi' premium grade, $\mathrm{M} \pm \mathrm{m}, \mathrm{n}=5$

\begin{tabular}{|c|c|c|c|c|c|}
\hline \multirow{3}{*}{$\begin{array}{c}\text { Name } \\
\text { of indicators }\end{array}$} & \multirow{3}{*}{$\begin{array}{l}\text { DSTU } \\
\text { requir- } \\
\text { ements }\end{array}$} & \multicolumn{4}{|c|}{ Tested samples, Bq/kg } \\
\hline & & Sample & Sample & Sample & Sample \\
\hline & & 1 & 2 & 3 & 4 \\
\hline${ }^{137} \mathrm{Cs}$ & 200 & $\begin{array}{c}5.31 \\
\pm 0.21\end{array}$ & $\begin{array}{c}6.33 \\
\pm 0.19\end{array}$ & $\begin{array}{c}4.53 \\
\pm 0.13\end{array}$ & $\begin{array}{c}5.44 \\
\pm 0.61\end{array}$ \\
\hline${ }^{90} \mathrm{Sr}$ & 20 & $\begin{array}{c}0.53 \\
\pm 0.14\end{array}$ & $\begin{array}{c}0.64 \\
\pm 0.22\end{array}$ & $\begin{array}{c}0.46 \\
\pm 0.37\end{array}$ & $\begin{array}{c}0.53 \\
\pm 0.21\end{array}$ \\
\hline
\end{tabular}

Thus, the analysis of the results of research on the quality of sausages of the premium grade 'Dytiachi' found that the test products 'sample 3' does not meet the requirements of the national standard for the mass fraction of salt, which is unacceptable, especially for products approved to be used by children.

Conclusions. Labeling of packaging of tested samples of sausages 'Dytiachi' contains basic production and consumer information in accordance with paragraph 1 of article 6 of the Law of Ukraine 'About information for consumers about food products' (VRU, 2019).

However, none of the samples contains information on the mass content of saturated fats and salt, moreover the carbohydrate content is indicated only on the label of sample No.2, which violates the requirements of article 23 of this law.

When labeling test samples No.1, 2, and 4, manufacturers use the statement 'Recommended for diet of preschool children (from 3 years) and school age', which is consistent with the text of DSTU 4436:2005 'Boiled sausages, frankfurters, sardellas, meat loaves. General specifications' (DSSU, 2006), but contradicts the 'Requirements for claims on the nutritional value of foods and claims on the health benefits of foods' (MHU, 2020).

According to the results of the study of chemical composition, it was found that in sample No. 2 the mass fraction of table salt was $2.11 \pm 0.14 \%$, which exceeds the content regulated by the state standard by $0.11 \%$.

\section{References}

Andryushchenko, D. S., Chekhova, E. A., Gorlov, I. F. and Grigoryan, L. F. (2020) 'Structured sausages for children' [Strukturirovannye sosiski dlya detey], Food Innovation and Biotechnology: abstracts of the VIII international scientific conference of students, graduate students and young scientists. Volume 1. Biotechnology, Quality and Safety [Pishchevye innovatsii $i$ biotekhnologii: sbornik tezisov VIII mezhdunarodnoy nauchnoy konferentsii studentov, aspirantov $i$ molodykh uchenykh (Kemerovo, 25-27 maya 2020 g., Kemerovo). Tom 1. Biotekhnologii, kachestvo i bezopasnost']. Kemerovo: Kemerovo State University. pp. 148-149. Available at: https://www. elibrary.ru/item.asp?id=43145765. [in Russian].

Bogatko, N. M., Bogatko, L. M., Salata, V. Z., Semaniuk, V. I., Serdioucov, Ya. K. and Schyrevuch, G. P. (2017) 'Veterinarysanitary control of safety and quality of meat products' [Veterynarno-sanitarnyi kontrol bezpechnosti ta yakosti miasnykh produktiv], Scientific Messenger of Lviv National University of Veterinary Medicine and Biotechnologies named after S. Z. Gzhytskyj. Series: Veterinary Sciences [Naukovyi visnyk Lvivskoho natsionalnoho universytetu veterynarnoi medytsyny ta biotekhnolohii imeni S. Z. Gzhytskoho. Seriia: Veterynarni nauky], 19(73), pp.7-10. doi: 10.15421/nvlvet 7302. [in Ukrainian].

Buts, M. A. (2017) 'Formation of the culture of healthy nutrition of schoolchildren' [Formuvannia kultury zdorovoho kharchuvannia shkoliariv], Young Scientist [Molodyi vchenyi], 9.1, pp. 13-16. Available at: http://nbuv.gov.ua/UJRN/molv_ 2017_9.1_6.[in Ukrainian]

CMU (Cabinet of Ministers of Ukraine) (2021) 'The order of organization of food in educational institutions and children's health and recreation institutions: approved by the resolution of the Cabinet of Ministers of Ukraine of 24 March 2021 No. 305' [Poriadok orhanizatsii kharchuvannia u zakladakh osvity ta dytiachykh zakladakh ozdorovlennia ta vidpochynku: zatverdzheno postanovoiu Kabinetu Ministriv Ukrainy vid 24 bereznia 2021 r. № 305], Government Courier [Uriadovyi kurier], 66. Available at: https://zakon.rada.gov.ua/ laws/305-2021-\%D0\%BF\#n148. [in Ukrainian].

DSSU (State Committee for Technical Regulation and Consumer Policy) (2005a) DSTU ISO 6888-2:2003 (ISO 68882:1999, IDT). Microbiology of Food and Animal Feeding Stuffs. Horizontal Method for the Enumeration of Coagulase-Positive Staphylococci (Staphylococcus Aureus and Other Species). Part 2: Technique Using Rabbit Plasma Fibrinogen Agar Medium [Mikrobiolohiia kharchovykh produktiv $i$ kormiv dlia tvaryn. Horyzontalnyi metod pidrakhuvannia koahulazopozytyvnykh stafilokokiv (Staphylococcus aureus ta inshykh vydiv). Chastyna 2. Metod $z$ vykorystanniam fibrynohenu plazmy krovi krolyka dlia aharovoho seredovyshcha]. Kyiv: Derzhspozhyvstandart Ukrainy. [in Ukrainian].

DSSU (State Committee for Technical Regulation and Consumer Policy) (2005b) DSTU ISO 11290-2:2003 (ISO 11290-2:1998, IDT). Microbiology of Food and Animal Feeding Stuffs. Horizontal Method for the Detection and Enumeration of Listeria monocytogenes. Part 2: Enumeration Method [Mikrobiolohiia kharchovykh produktiv ta kormiv dlia tvaryn. Horyzontalnyi metod vyiavlennia ta pidrakhuvannia Listeria monocytogenes. Chastyna 2. Metod pidrakhuvannia]. Kyiv: Derzhspozhyvstandart Ukrainy. [in Ukrainian]. 
DSSU (State Committee for Technical Regulation and Consumer Policy) (2005c) DSTU EN 12824:2004 (EN 12824:1997, IDT). Microbiology of Food and Animal Feeding Stuffs. Horizontal Method for the Detection of Salmonella [Mikrobiolohiia kharchovykh produktiv i kormiv dlia tvaryn. Horyzontalnyi metod vyiavlennia Salmonella]. Kyiv: Derzhspozhyvstandart Ukrainy. [in Ukrainian].

DSSU (State Committee for Technical Regulation and Consumer Policy) (2006) DSTU 4436:2005. Boiled sausages, frankfurters, sardellas, meat loaves. General specifications [Kovbasy vareni, sosysky, sardelky, khliby miasni. Zahalni tekhnichni umovy]. Kyiv: Derzhspozhyvstandart Ukrainy. [in Ukrainian].

DSSU (State Committee for Technical Regulation and Consumer Policy) (2008a) DSTU 4823.2:2007. Meat Products. Organoleptical Evaluation of Quality Characteristics. Part 2. General Requirements [Produkty miasni. Orhanoleptychne otsiniuvannia pokaznykiv yakosti. Chastyna2. Zahalni vymohy]. Kyiv: Derzhspozhyvstandart Ukrainy. [in Ukrainian].

DSSU (State Committee for Technical Regulation and Consumer Policy) (2008b) DSTU ISO 4833:2006 (ISO 4833:2003, IDT). Microbiology of Food and Animal Feeding Stuffs. Horizontal Method for the Enumeration of Microorganisms. Colony-Count Technique at $30^{\circ} \mathrm{C}$ [Mikrobiolohiia kharchovykh produktiv i kormiv dlia tvaryn. Horyzontalnyi metod pidrakhunku mikroorhanizmiv. Tekhnika pidrakhuvannia kolonii za temperatury $30^{\circ} \mathrm{C}$. Kyiv: Derzhspozhyvstandart Ukrainy. [in Ukrainian].

Hashchuk, O. I., Moskaliuk, O. Ye. and Fedorko, I. A. (2014) 'Expansion of the range of meat products for nutrition of school-age children' [Rozshyrennia asortymentu miasnykh produktiv kharchuvannia ditei shkilnoho viku], Scientific Messenger of Lviv National University of Veterinary Medicine and Biotechnologies named after S.Z. Gzhytskyj [Naukovyi visnyk Lvivskoho natsionalnoho universytetu veterynarnoi medytsyny ta biotekhnolohii imeni S. Z. Gzhytskoho], 16(2.4), pp. 37-42. Available at: http://nbuv.gov.ua/UJRN/nvlnu_2014 _16_2(4)_8. [in Ukrainian].

Hashchuk, O. I., Moskaliuk, O. Ye. and Simonova, I. I. (2020) 'Development of meat products recipes for baby nutrition with therapeutic and preventive action' [Rozroblennia retseptur miasnykh produktiv dlia dytiachoho kharchuvannia likuvalno-profilaktychnoi dii], $10^{\text {th }}$ International Scientific and Practical Conference 'Topical Issues of the Development of Modern Science' (Sofia, Bulgaria, 4-6 June 2020). Sofia, Bulgaria: Accent, pp. 214-223. Available at: http://dspace.nuft. edu.ua/jspui/handle/123456789/31735 [in Ukrainian].

Khimich, M. S., Salata, V. Z., Piven, O. T., Salata, R. V., Koreneva, Z. B. and Naidich, O. V. (2020) 'Veterinary-sanitary evaluation of high-class boiled sausage 'Likarska" [Veterynarnosanitarna otsinka kovbasy varenoi vyshchoho sortu 'Likarska'], Scientific Messenger of Lviv National University of Veterinary Medicine and Biotechnologies named after S. Z. Gzhytskyj. Series: Veterinary Sciences [Naukovyi visnyk Lvivskoho natsionalnoho universytetu veterynarnoi medytsyny ta biotekhnolohii imeni S.Z. Gzhytskoho. Seriia: Veterynarni nauky], 22(98), pp. 36-41. doi: 10.32718/nvlvet9806. [in Ukrainian].

Kotelevych, V. A. and Larina, K. S. (2020) 'Veterinary and sanitary evaluation of sausage products in Zhytomyr according to quality and safety indicators' [Veterynarno-sanitarna otsinka kovbasnykh vyrobiv u misti Zhytomyr za pokaznykamy yakosti ta bezpechnosti], Scientific Messenger of Lviv National University of Veterinary Medicine and Biotechnologies named after S. Z. Gzhytskyj. Series: Veterinary Sciences [Naukovyi visnyk Lvivskoho natsionalnoho universytetu veterynarnoi medytsyny ta biotekhnolohii imeni S. Z. Gzhytskoho. Seriia:
Veterynarni nauky], 22(97), pp. 112-117. doi: 10.15421/nvlvet 9718. [in Ukrainian].

Merkulova, T. V., Peresypkina, T. V., Avdiievska, O. H. and Cherniakova, H. M. (2020) 'To the question of organisation school feeding' [Do pytannia orhanizatsii kharchuvannia ditei v zakladakh zahalnoi serednoi osvity], Clinical and Preventive Medicine [Klinichna ta profilaktychna medytsyna], 2(12), pp. 54-61. doi: 10.31612/2616-4868.2(12).2020.02. [in Ukrainian].

MHU (Ministry of Health of Ukraine) (2020) 'Requirements for claims on the nutritional value of foods and claims on the health benefits of foods: approved by the order of the Ministry of Health of Ukraine of 15 May 2020 No. 1145' [Vymohy do tverdzhen pro pozhyvnu tsinnist kharchovykh produktiv ta tverdzhen pro koryst dlia zdorovia kharchovykh produktiv: zatverdzheno nakazom Ministerstva okhorony zdorovia Ukrainy vid 15 travnia 2020 r. № 1145], Official Herald of Ukraine [Ofitsiinyi visnyk Ukrainy], 65, art. 2116. Available at: https://zakon.rada.gov.ua/laws/z0745-20\#n15. [in Ukrainian].

Nyankovskyy, S. L. and Sadova, O. R. (2018) 'Eating behavior and quality of life in high school pupils in Lviv' [Kharchova povedinka ta yakist zhyttia shkoliariv starshykh klasiv m. Lvova], Child's Health [Zdorovia dytyny], 13(1), pp. 40-47. doi: 10.22141/2224-0551.13.1.2018.127065. [in Ukrainian].

Paliy, A. P., Stegniy, B. T., Palii, A. P., Rodionova, K. O., Bogatko, N. M., Vashchyk, Ye. V., Sakhniuk, N. I., Ovcharenko, H. V., Dudus, T. V., Ihnatieva, T. M. and Kovalenko, L. V. (2020) 'Microstructural analysis of sausage quality', Ukrainian Journal of Ecology, 10(2), pp. 404-409. doi: 10.15421/2020_115.

Rodionova, K. O. and Paliy, A. P. (2018) 'Influence of modern vacuum packaging on quality and safety of sausage products', Journal for Veterinary Medicine, Biotechnology and Biosafety, 4(1), pp. 18-23. doi: 10.36016/JVMBBS-2018-4-1-4.

Romaniuk, T. M. (2019) 'Features of the assessment of the competitiveness of sausages and sausages' [Osoblyvosti otsinky konkurentospromozhnosti sosysok i sardelok], Bulletin of Student Scientific Society 'Vatra' of Vinnitsa Trade And Economic Institute of Kyiv National Trade And Economic University [Visnyk studentskoho naukovoho tovarystva 'VATRA' Vinnytskoho torhovelno-ekonomichnoho instytutu Kyivskoho natsionalnoho torhovelno-ekonomichnoho universytetu], 77, pp. 260-266 Available at: http://www.vtei. com.ua/konfa/23_05_19/16_77.pdf [in Ukrainian].

SE 'UkrNDNC' (Ukrainian Research and Training Center of Standardization, Certification and Quality) (2016) DSTU ISO 15213:2014 (ISO 15213:2003, IDT). Microbiology of Food and Animal Feeding Stuffs. Horizontal Method for the Enumeration of Sulfite-Reducing Bacteria Growing Under Anaerobic Conditions [Mikrobiolohiia kharchovykh produktiv ta kormiv dlia tvaryn. Horyzontalnyi metod pidrakhovuvannia kilkosti sulfitovidnovliuvalnykh bakterii, yaki rostut $v$ anaerobnykh umovakh]. Kyiv: SE 'UkrNDNC'. [in Ukrainian].

SE 'UkrNDNC' (Ukrainian Research and Training Center of Standardization, Certification and Quality) (2018) DSTU ISO 4832:2015 (ISO 4832:2006, IDT). Microbiology of Food and Animal Feeding Stuffs. Horizontal Method for the Enumeration of Coliforms. Colony-Count Technique [Mikrobiolohiia kharchovykh produktiv ta kormiv dlia tvaryn. Horyzontalnyi metod pidrakhuvannia koliform. Metod pidrakhuvannia kolonii]. Kyiv: SE 'UkrNDNC'. [in Ukrainian].

Skrypka, M. V., Tarasenko, L. O., Panikar, I. I., Rud, V. O. and Prylipko, T. M. (2020) 'Control of sausage production in accordance with the requirements of the state standard' [Kontrol vyrobnytstva kovbasnykh vyrobiv vidpovidno do vymoh derzhavnoho standartu], Integration of Education, Science and Business in the Modern Environment: Winter 
Debates: abstracts of the $1^{\text {st }}$ international scientific and practical internet conference (6-7 February 2020) [Intehratsiia osvity, nauky ta biznesu $v$ suchasnomu seredovyshchi: zymovi dysputy: tezy dopovidei I mizhnarodnoi naukovo-praktychnoi internetkonferentsii (6-7 liutoho 2020 r.)], 3, pp. 209-214. Available at: http://www.wayscience.com/wp-content/uploads/2020/02/TOM-3Zbirnik-1-mizhnarodna-nauk-prakt-int.-konf-Winter-Debates-1.pdf. [in Ukrainian].

Tytarenko, O. O. (2020) 'Chemical additives in food' [Khimichni dobavky u produktakh kharchuvannia], Safety of Human Life and Activity: Theory and Practice: a collection of scientific papers of the All-Ukrainian scientific-practical conference dedicated to the World Days of Civil Defense and Labor Protection (Poltava, 23-34 April 2020) [Bezpeka zhyttia $i$ diialnosti liudyny: teoriia ta praktyka: zbirnyk naukovykh prats Vseukrainskoi naukovo-praktychnoi konferentsii, prysviachenoi Vsesvitnim Dniam tsyvilnoi oborony ta okhorony pratsi (Poltava, 23-24 kvitnia 2020 r.). Poltava: Poltava V. G. Korolenko National Pedagogical University, pp. 143-146. Available at: http://dspace. pnpu.edu.ua/handle/123456789/14838. [in Ukrainian].
Voitsitska, O. M. (2019) 'Recipes making for children's boiled sausages' [Rozrobka retseptur dytiachykh varenykh sosysok], Agrarian Science and Food Technologies [Ahrarna nauka ta kharchovi tekhnolohii], 1, pp. 170-175. Available at: http://nbuv.gov.ua/UJRN/anxt_2019_1_20. [in Ukrainian].

VRU (Verkhovna Rada Ukrainy) (2019) 'Law of Ukraine No. 2639-VIII of 06.12.2018 'About information for consumers about food products” [Zakon Ukrainy № 2639-VIII vid 06.12.2018 'Pro informatsiiu dlia spozhyvachiv shchodo kharchovykh produktiv'], News of the Verkhovna Rada of Ukraine [Vidomosti Verkhovnoi Rady Ukrainy], 7, art. 41. Available at: https://zakon.rada.gov.ua/laws/2639-19. [in Ukrainian].

Yevstafieva, V. O., Sorokova, V. V., Melnychuk, V. V. and Sorokova, S. S. (2017) 'Microstructural analysis of the quality of sausages of different types' [Mikrostrukturnyi analiz yakosti kovbasnykh vyrobiv riznykh vydiv], Problems of Zooengineering and Veterinary Medicine [Problemy zooinzhenerii ta veterynarnoi medytsyny], 35(2.2), pp. 207-211. Available at: http://nbuv.gov. ua/UJRN/pzvm_2017_35(2.2)_51. [in Ukrainian]. 